\title{
Homodimerization of $\mathrm{APOBEC} 3 \mathrm{G}$ is required for inhibition of Alu retrotransposition
}

\author{
Yukie Iwabu', Juan F Arias ${ }^{1}$, Masaru Yokoyama², Hironori Sato², Tetsutaro Sata' ${ }^{1}$, Kenzo Tokunaga ${ }^{1 *}$ \\ From Frontiers of Retrovirology 2011 \\ Amsterdam, The Netherlands. 3-5 October 2011
}

\section{Background}

Alu elements are active non-LTR retrotransposons that account for approximately $11 \%$ of the human genome and are known to be not only the cause of genetic disease in germinal cells, but have also been implicated on the development of B-cell lymphomas suggesting they affect the genome of somatic cells as well. In the present study, the molecular mechanisms of the inhibitory activity of human APOBEC3 (A3) family members on Alu retrotransposition were investigated.

\section{Materials and methods}

A3 family proteins were tested in a neomycin-resistant $\left(\right.$ neo $\left.^{r}\right)$-based retrotransposition assay. Briefly, HeLa cells were cotransfected with a neo ${ }^{\mathrm{r}}$-Alu reporter vector, LINE-1 ORF2 vector and the respective A3 expression plasmids. Seventy-two hours post-transfection, G418 was added for resistance selection, and after 14 days resultant G418-resistant colonies were fixed, stained with crystal violet and counted. A series of APOBEC3G (A3G) mutants bearing deletions in the $\mathrm{N}$-terminus in multiples of 30 amino acids (aa) were constructed to evaluate the responsible region. Likewise, dimerization and deamination deficient A3G mutants were also created to examine the inhibitory effect of A3G on Alu retrotransposition.

\section{Results}

The neo ${ }^{\mathrm{r}}$-based retrotransposition assay showed that all hA3 family proteins differentially inhibited Alu retrotransposition. By the deletion analyses based on A3G that is the most well-characterized A3 family member, the N-terminal 30 aa of A3G was found to determine its inhibitory activity on Alu retrotransposition. Mutational analyses showed that the inhibitory activity of A3G was

'Department of Pathology, National Institute of Infectious Diseases, Tokyo, 162-8640, Japan

Full list of author information is available at the end of the article independent of its deaminase activity, but dependent on its dimerization, which was found to be affected by deletion in its N-terminal 30 aa. Importantly, the dimerization of A3G was also required for the inhibition of LINE-1 retrotransposition.

\section{Conclusions}

The N-terminal 30 aa of A3G are essential for its inhibitory activity on Alu retrotransposition, and this correlates with A3G homodimerization. The structural basis for the effect of the N-terminal 30 aa region of A3G on its dimerization is currently under investigation.

\section{Author details}

'Department of Pathology, National Institute of Infectious Diseases, Tokyo, 162-8640, Japan. ${ }^{2}$ Pathogen Genomics Center, National Institute of Infectious Diseases, Tokyo, 162-8640, Japan.

Published: 3 October 2011

\section{doi:10.1186/1742-4690-8-S2-P67}

Cite this article as: Iwabu et al: Homodimerization of APOBEC3G is required for inhibition of Alu retrotransposition. Retrovirology 20118 (Suppl 2):P67.

Submit your next manuscript to BioMed Central and take full advantage of:

- Convenient online submission

- Thorough peer review

- No space constraints or color figure charges

- Immediate publication on acceptance

- Inclusion in PubMed, CAS, Scopus and Google Scholar

- Research which is freely available for redistribution

\section{Biomed Central}

(c) 2011 Iwabu et al; licensee BioMed Central Ltd. This is an open access article distributed under the terms of the Creative Commons Attribution License (http://creativecommons.org/licenses/by/2.0), which permits unrestricted use, distribution, and reproduction in any medium, provided the original work is properly cited. 